\title{
O Clichê: notas para uma derrota do pensamento. Por uma consciếncia ingênua
}

Flávio Henrique Albert Brayner'

'Universidade Federal de Pernambuco (UFPE), Recife/PE - Brasil

RESUMO - O Clichê: notas para uma derrota do pensamento. Por uma consciência ingênua. Em que sentido o clichê, a frase feita e repisada, o jargão - que já há algum tempo invadiram o vocabulário pedagógico - podem representar uma estratégia de refamiliarização com um mundo tornado estranho, em que nossos conceitos deixaram de ser adequados, e passaram a indicar um perigo para o pensamento? Partindo de uma imagem de Camus (Sísifo) e passando pelo exame de Arendt sobre o caso Eichmann, em que o clichê é associado a uma derrota do pensamento, o artigo propõe uma tarefa insólita: um retorno a uma consciência ingênua, não como relação beata e desarmada diante do mundo, e sim como produção de um novo dicionário capaz de vivificar, linguisticamente, a atitude ad-miração diante das coisas. Palavras-chave: Linguagem. Derrota do Pensamento. Estranhamento do Mundo. Consciência Ingênua.

ABSTRACT - The Cliché: notes for a defeat of thought. For a naïve consciousness. In which way can the cliché, the ready-made, ceaselesslyrepeated sentence, the jargon - which have invaded pedagogical vocabulary for quite some time already - represent a strategy for being reacquainted to a world turned strange, where our concepts are no longer appropriate, and have become an indication of danger to thought? From Camus' image of Sisyphe through Arendt's examination of the Eichmann's case, where the cliche is associated to a defeat of thought, the article proposes a bizarre task: a return to a naive consciousness, not as a gaping and disarmed relation to the world, but as a production of a new dictionary, capable of livening up, linguistically speaking, a stand of ad-miration before things.

Keywords: Language. Defeat of Thought. Strangeness in Estrangement of the World. Naive Consciousness.

Educação \& Realidade, Porto Alegre, v. 39, n. 2, p. 557-572, abr./jun. 2014.

Disponível em: <http://www.ufrgs.br/edu_realidade> 
Sabemos agora que se o Verbo foi o início de tudo, poderá igualmente encontrar-se no fim (George Steiner).

\section{Algumas Palavras Iniciais...}

No célebre Mito de Sísifo um homem é condenado a rolar infinitamente uma pedra montanha acima e vê-la desfazer todo o seu trabalho descendo ladeira abaixo. O livro homônimo de Albert Camus (Camus, 2001) trata do absurdo da existência, metaforicamente representado nesse esforço sem sentido e sem fim. A ideia de absurdo se refere a uma espécie de desfamiliarização, em que o mundo se torna um lugar estranho e incompreensível e as palavras que usamos não são mais capazes de dar sentido à nossas experiências: é este advento do inefável que constitui o absurdo da vida. No livro de Camus, no entanto, quando a pedra atinge o cume da montanha, Sísifo senta-se e observa seu trabalho ser desfeito: este é o momento que Camus chama de consciência, a exata percepção do absurdo de sua tarefa e, como ela é infinita, de toda a sua vida.

Talvez estejamos vivendo uma dessas épocas de desfamiliarização com o mundo expressa nas repetidas ideias de que os valores agora são outros, no meu tempo era diferente, os tempos estão mudados..., frases provavelmente repetidas por cada geração, mas que, mesmo em sua banalidade, atestam o fato de que se criou um espaço vazio (mesmo que temporário) entre o que acontece no mundo e a capacidade que temos de dar nome a estes acontecimentos. Abre-se uma época camuseana que atinge essencialmente a relação entre as palavras e as coisas - lembro, aqui, o exemplo do Quixote à procura das coisas do mundo que correspondessem às suas leituras de romances medievais de cavalaria -, e isso em diversos domínios da realidade, inclusive o pedagógico. Trata-se de uma situação preocupante e, para tentar esclarecê-la, sugiro a hipótese de que uma das estratégias que podemos utilizar para suportar esta desfamiliarização (que atinge fortemente o nosso meio) se dá através do clichê, da frase feita, do lugar comum, da ideia repisada e batida.

O artigo que o leitor tem agora sob os olhos será desenvolvido em três etapas. Num primeiro momento, procedo a um exame das consequências do uso do clichê e sua relação com uma previsível débâcle de nossa capacidade de pensar. Em seguida, através da conhecida obra de Hannah Arendt sobre Eichmann (Arendt, 1997), aprofundo o tema tentando mostrar que tal débâcle tem uma relação direta com a ideia de banalidade do mal: a ausência de profundidade que nos impede, via clichê/ideologia, de ter experiências e dispor de capacidade de julgar aquilo que nos acontece. E mais adiante, depois de uma rápida passagem pela Alegoria da Caverna, em que procuro mostrar a venenosa armadilha em que Platão nos meteu, fecho este ensaio mostrando como a invasão do clichê no domínio da Educação Popular tem subtraído desta 
área sua original energia crítica e proponho - admito que de forma polêmica e heterodoxa - uma espécie de retorno a uma ingenuidade, não como relação beata e desarmada diante da realidade, mas como estratégia de ad-miração e estranhamento para evitar os automatismos do pensar, que o clichê forçosamente encarna.

Há pouco foi publicada uma obra (de inspiração flaubertiana, mas de tendência anarquizante!) chamada Dicionário das Ideias Feitas em Educação, de Sandra Maria Corazza e Júlio Groppa Aquino (Aquino; Corazza, 2011), título que remete ao célebre Dictionnaire des Idées Reçues de Gustave Flaubert, e que toca num assunto que atinge particularmente a educação: o verdadeiro abuso que nossos redatores de textos educativos (sob a forma de artigos, livros, conferências, relatórios, intervenções várias) fazem do jargão e da construção frasal banal e vazia. Por um perdoável descuido dos autores, o Dicionário acima lembrado, apesar de sua longa e divertida introdução, não toca no principal: por que uma língua e seu dicionário, quer dizer, o conjunto lexical de um determinado campo de conhecimento, a partir do qual podemos conotar e denotar os objetos que aparecem no horizonte de nossas interações linguísticas sofre tal processo de banalização semântica expressa na repetição impensada? Por que precisamos deste recurso comunicativo e qual a intenção de quem apela para tal expediente?

Estou certo de que todos nós, educadores e leitores sistemáticos de documentos escritos em nosso domínio, encontramos ordinariamente expressões do tipo consciência crítica, formação para a cidadania, qualidade social da educação, educação socialmente referenciada, problematização da realidade, perspectiva epistemológica, transitividade da consciência, perspectiva do campo emancipatório, visada neoliberal, resgatar a utopia e tantas e tantas outras que fazem o imenso - e não raras vezes vazio - repertório conceitual de nosso território. Há algo de profundamente inquietante em tudo isto porque não se trata apenas do uso repetitivo de expressões típicas de um universo profissional (uma política linguística de identidade e pertencimento), mas sim, de um mecanismo que se assemelha ao que os latinos conheciam como captatio benevolenciae. Em sua versão moderna, trata-se de um recurso de retórica, adquirido através de técnicas discursivas conhecidas que, logo no início da locução, estabelece uma relação empática entre retor e auditor. Esse recurso não tem a intenção de facilitar a compreensão, mas sim de estabelecer um pacto de cumplicidade em que, pelo uso de vocabulário ideologicamente familiar e frases de recepção fácil e previsível, estabelece-se uma relação (aliás, muito pouco crítica!) de identidade entre quem produz e quem consome frases e ideias de digestão rápida (o clichê).

Usei propositalmente o verbo consumir porque ele me reenvia à passagem de Hannah Arendt (Arendt, 1997) a respeito de como a modernidade transformou os produtos do Trabalho - que na sua concepção são aqueles produtos da cultura que nós produzimos para assegurar um 
O Clichê

quadro de vida propriamente humano - nossa casa - e que devem permanecer como legado físico e perene de nossa passagem por um mundo comum e que garantem a sua durabilidade -, em produtos de consumo imediato (característica do Labor), que têm a função de assegurar nossa simples sobrevivência (como os alimentos) e fadados a desaparecer quase que imediatamente após serem produzidos. Esse consumo, que em algum ponto lembra os conceitos frankfurtianos de indústria cultural e de entretenimento (Adorno; Horkheimer, 1987), aponta para a ausência de perenidade do mundo e de suas significações, como se os conceitos (transformados em jargões, clichês, lugares comuns) fossem elaborados não mais para ajudar a fornecer significado para nossas experiências eventuais, mas para desaparecerem (consumidos) assim que pronunciados: o jargão facilita um rápido metabolismo conceitual (pela sua familiaridade) e nos fornece a impressão de estarmos num terreno comum, num horizonte semântico e valorativo com o qual nos identificamos in limine. E aquele que o pronuncia nos atrai para seu campo e determina logo de saída, em qual terreno vai-se jogar o jogo das significações. Em resumo: ele nos instala numa área semântica proposta pelo próprio enunciador.

Isto significa dizer que a forma (a linguagem utilizada) tem uma tão decisiva influência sobre o conteúdo (mesmo aquele que em educação pretendemos crítico), que esta criticidade se esvazia na medida em que o clichê representa, justamente, aquilo que nos poupa de pensar, que nos impede de nos deslocarmos de nossos hábitos de pensamento e que poderia permitir uma espécie de VerfremdüngsEffekt, um efeito de distanciamento crítico. O jargão é, assim, uma das inúmeras formas que pode assumir a derrota do pensamento. Se a linguagem for entendida não como um medium ou um canal pelo qual exprimimos pensamentos e ideias, mas aquilo que permite exatamente a possibilidade de pensar - e sem o que o próprio ato de pensar se torna impossível -, podemos concluir que a deterioração da linguagem é a expressão mais visivel/audível do declínio da capacidade de pensar e de refletir (quer dizer, o pensamento que se debruça sobre si mesmo e se pensa) $)^{1}$.

A linguagem que utilizamos numa determinada área do saber não constitui um léxico e uma sintaxe neutras que poderiam, sem prejuízo, ser usadas em qualquer outro domínio. Trabalhamos sempre com aquilo que Umberto Eco (Eco, 2004) chamou de um dicionário. Este dicionário é o conjunto de verbetes que nos permite exprimir ideias de uma determinada forma e que pode ser compreendido por pessoas que conheçam também tal léxico. Aquilo que chamamos de formação do professor (para me restringir ao nosso campo) não é outra coisa senão os exercícios de familiarização lexical que nos permitem elaborar e visualizar os objetos conceituais da educação. É uma das múltiplas estratégias de distribuição seletiva de palavras no ambiente social e do controle sobre quem as utiliza, como o faz, onde e em que interação linguística: sem este léxico os conceitos de nossa área não fariam sentido, 
e fora do ambiente onde são pronunciados eles são incompreensíveis. Quando as palavras se constituem em conceitos, estes só ganham inteligibilidade em sua relação com outros conceitos e no interior de um conjunto articulado de conceitos, que poderíamos chamar de um sistema de pensamento. Por exemplo: a palavra trabalho que podemos usar comumente referindo-nos à nossa atividade profissional, no interior da teoria marxista do valor-trabalho é algo completamente diferente. Podemos dizer que num caso fazemos uso conceitual de uma palavra, no outro um uso ordinário de um léxico que utilizamos em nossas interações cotidianas.

O jargão, o clichê, a frase feita produzem algo que, ao procurar compensar o vácuo da experiência sisífica, nos remetem a um excesso de familiaridade: seu uso nos faz crer que o mundo que estamos designando corresponde de fato à sua designação, em que significante e significado não entram em tensão e que, assim, trata-se de um universo conhecido e familiar, quando, na verdade, a única coisa familiar aqui é o próprio léxico. O clichê, assim, nos permitiria realizar uma operação de suma importância em nossa relação com o mundo (mundo entendido como o conjunto de nossas experiências só possíveis no interior da linguagem): evitar a fratura, a esquizofrenia entre as coisas ditas ou representadas no interior da linguagem e os objetos a que elas se referem. Como cada corpus ideológico possui seu léxico, ao ler palavras como conscientização, problematização, transitividade, transformação ou dialogicidade, num texto ou artigo qualquer (e penso, aqui, sobretudo na área da Educação Popular), imediatamente podemos identificar a inspiração teórica de seu autor e - se for o caso - estabelecer com ele uma empatia de entrada, uma adesão preliminar, como uma senha que precisássemos pronunciar ou ouvir para produzir identificações.

Suponhamos, no entanto, que essas palavras não correspondam mais às coisas do mundo (que só existem, como na velha Macondo de García Marquez atingida pelo esquecimento, se nas coisas colarmos as palavras!); que, por exemplo, entendamos que a palavra conscientização corresponda a uma época em que ainda supúnhamos um sujeito autocentrado, dotado de uma consciência autônoma e capaz de se dar a própria norma segundo critérios universais e que, hoje, descobríssemos que este sujeito nunca existiu e que precisaríamos redescrevê-lo de outra forma. É como se abríssemos aqui um abismo entre a coisa e o seu nome... Como ninguém é obrigado a aceitar a hipótese pós-moderna sobre o sujeito e a consciência, e pode permanecer insistindo na ideia de uma consciência que pode libertar ou ser libertada por uma ação educativa de natureza emancipatória, não haveria problema: o léxico que ele usa corresponde (na sua cabeça) a coisas que ainda existem e que só os pós-estruturalistas, os nietzscheanos, os foucaultianos, os deleuzianos acham que não, com os quais não somos obrigados a concordar. E é aqui onde o clichê cumpre sua importantíssima função: ele permite ao seu leitor ver algo na realidade independentemente de sua

Educação \& Realidade, Porto Alegre, v. 39, n. 2, p. 557-572, abr./jun. 2014. 
existência, digamos, objetiva. Faz mais do que isto: o clichê nos remete a um mundo seguro, conhecido e estável, onde as ideias fazem sentido, correspondem a certas práticas, pertencem a um sistema articulado de pensamento (uma narrativa com começo, meio e fim) e nos fornece o calor aconchegante de pertencer a uma comunidade de sentido. O clichê é a forma linguística da nostalgia uterina em uma época de incertezas, inconsistências e instabilidades identitárias.

\section{Da Derrota do Pensamento à Banalidade do Mal}

O problema não está no uso banal e repetitivo de frases, ideias ou palavras, retirando delas sua força de significação e afastando-as da experiência. A gravidade do fato reside numa instância de metragem bem mais profunda: ao romper com a experiência, rompe-se com o outro e com o mundo, quando a existência do outro passa a ser algo, para sermos exatos, in-significante (sem significação no interior da linguagem e, portanto, como conjunto vazio). Para exemplificar de forma mais incisiva o que acabo de dizer, ofereço, a seguir, um exame do caso Eichmann, descrito e comentado por Hannah Arendt em seu célebre livro. Em 1961, Adolf Eichmann, após ter sido sequestrado por um comando israelense num subúrbio de Buenos Aires e levado para Jerusalém, foi julgado pelos crimes contra a humanidade praticados sob o Nazismo. Eichmann trabalhou inicialmente em Viena e em seguida em Berlin e Praga, no setor do Reich que tratava do reagrupamento e deportação de judeus, assunto no qual em sua malsã vaidade considerava-se um especialista.

Naquele mesmo ano, Hannah Arendt solicitou ao The New Yorker financiamento para acompanhar o julgamento, em troca de um conjunto de artigos a serem publicados pela Revista. Posteriormente, em 1963, ela publicou o seu Eichmann in Jerusalem. Report of a Banality of Evil $^{2}$, livro que lhe valeu uma segunda celebridade mundial (sendo a primeira após a publicação de As Origens do Totalitarismo), mas desta vez acompanhada de uma violenta polêmica, de incontáveis mal-entendidos, da encarniçada reação da comunidade judaica internacional e de ataques e difamações pessoais. Os termos em que se deu a polêmica - e a posição pessoal de Arendt - podem ser acompanhados através da obra de Young-Brühel (Young-Brühel, 1997), do prefácio à edição francesa escrito por Michelle-Irène Brudny de Launay, da correspondência com Jaspers e com Mary MacCarthy e do Post-scriptum à própria obra.

O essencial, a meu ver, deste livro, é que ali onde as pessoas procuravam um monstro, Arendt vê uma pessoa normal, desinteressante, sem nenhuma grande afetação psicológica dilacerante que explicasse uma suposta desumanidade do personagem. Mais do que normal, Arendt vê em Eichmann um medíocre: um homem que só fala através de clichês, incapaz de uma frase original, que só conhece a linguagem administrativa. E é esta normalidade que constrange! Se o Nazismo é 
uma obra de homens normais e não de monstros perfeitamente deformados em sua humanidade, todos nós, pessoas supostamente normais, podemos num momento ou noutro ser tentados a repeti-lo ou a reinventá-lo. Demonizar seus atores é dizer que estamos longe da sedução de praticá-lo, que estamos imunes à sua tentação.

O ponto seminal daquele livro é a relação que a autora estabelece entre ausência de pensamento - expressa no clichê - e a prática do mal. Inúmeros comentaristas de sua obra (Roviello; Collin; Brühel, etc. Vide bibliografia) assinalam esta relação; no entanto, as passagens que sugerem tal relação são, no corpo do livro, extremamente sumárias. $\mathrm{Na}$ edição francesa encontramos a seguinte passagem a respeito de Eichmann:

Quanto mais o escutávamos, mais nos rendíamos à evidência de que sua capacidade de se exprimir estava ligada à sua incapacidade de pensar - de pensar especialmente do ponto de vista do outro. Era impossível se comunicar com ele, não porque ele mentia, mas porque ele se cercava de mecanismos de defesa extremamente eficazes contra as palavras dos outros, a presença do outro, contra a própria realidade (Arendt, 1994, p. 85-86).

É no post-scriptum ao livro, redigido no momento em que a polêmica e as acusações pessoais atingem seu ponto culminante, que aparece - mesmo assim de forma bastante avara - a tese: "Eichmann não era um estúpido. É a pura ausência de pensamento - o que não é a mesma coisa - que lhe permitiu tornar-se um dos maiores criminosos de sua época” (Arendt, 1994, p. 460). E na página seguinte uma simples linha em que a autora indica (esta) "[...] estranha ligação entre a ausência de pensamento e a prática do mal”.

Vimos que Eichmann não é alguém que sofre de uma deficiência cognitiva ou de simples estupidez: é sua incapacidade de distinguir o bem do mal, ligada à impotência do pensar que está na base do problema. Tendo rompido com toda alteridade, a dos outros, a de si mesmo e a do mundo, ele não se sente culpado, não experimenta nenhum remorso, nenhum arrependimento, porque nele a pluralidade do mundo é simplesmente inconcebível e sua impotência para o pensamento é correlativa à sua incapacidade de viver experiências. Eliminação do Outro que me habita; ruptura com o mundo da experiência e com a realidade, extermínio do outro externo; anulação das distinções entre o bem e o mal são os sintomas de uma mesma e única patologia: a débâcle do pensamento, expressa no uso linguístico do clichê, cuja função fica, agora, mais clara: produzir, ao mesmo tempo, distanciamento do mundo, como forma de autopreservação identitária e excesso de familiaridade. Ambas as injunções alvejando um único sentido: evitar a prática de pensar.

O clichê, assim, se constitui numa forma de subtrair as pessoas do exame crítico e fixá-las solidamente às regras de conduta de uma 
O Clichê

sociedade dada. Se decidir entre o bem e o mal é um atributo daqueles que guardam intacta a capacidade de pensar, é nas situações concretas que é necessário julgar, escolher e decidir entre o que podemos e o que não podemos fazer. Todo exame crítico deve atravessar uma fase de negação, ao menos hipotética, dos valores e opiniões correntes, passando ao crivo (cuja etimologia é a mesma de crítica) suas certezas tácitas e suas implicações e, neste caso, pode-se ver no niilismo (em um sentido não-nietzscheano) um risco que perpetuamente corre o pensamento: niilismo como recusa deliberada de ver na crítica um ato de potência e, nesta recusa, abandonar o pensamento, digamos assim, à sua própria sorte...

O que me parece claro, no entanto, nesta complexa relação é que nenhum pensamento é capaz de se livrar de uma vez por todas dos preconceitos (que o clichê tão bem representa), limite e ilusão talvez intransponível de toda educação iluminista. Se o pensar se subtrai do mundo aparente para se exercer e colocar os preconceitos sob tensão, voltar ao mundo fenomênico é novamente se abrir à influência do preconceito, em que reconhecemos referências aparentemente sólidas para agir em sociedade; sem isto, teríamos que permanecer em um insuportável estado de alerta permanente e colocar em questão, cotidianamente, todas as nossas experiências. Isto quer dizer que provavelmente nenhuma educação jamais conseguirá produzir a imunização integral dos indivíduos ao preconceito, ao pensamento herdado, às idées reçues. Mas também, se a atividade do pensamento é possível, jamais o preconceito pode se estabelecer de uma vez por todas. É esta tensão que faz com que ao mesmo tempo em que nos encontremos num mundo estruturado e dado (gerador do pré-conceito), somos poupados de ter que nos defrontarmos a todo momento com novas experiências e, a cada vez, este mesmo mundo seja interrogado (pensamento). As ideologias, no interior desta tensão, cumprem exatamente a função de impedir a experiência, oferecendo antecipadamente as respostas das questões que se colocam (Não me interessa a pergunta que você fará. A resposta éa luta de classes!'). Se a função do preconceito é defender o homem julgante para não se expor abertamente a cada realidade encontrada e daí ter de defrontá-la pensando, então as ideologias cumprem esta tarefa tão bem que protegem contra toda experiência, pois supostamente todo o real está nelas previsto de alguma maneira. E impedindo a experiência, impede, por conseguinte, o pensamento ${ }^{3}$.

Não é, pois, à toa que as doutrinas e corpusideológicos impermeáveis à erosão crítica (como nos regimes totalitários) façam tão constante apelo aos clichês e jargões; porque, no fundo, eles oferecem aos seus adeptos os instrumentos analíticos que os impedem de enxergar a realidade através de óculos que não sejam aqueles fornecidos pelo próprio sistema. Parece, assim, tais regimes praticam um esforço imenso para garantir o controle das palavras, adulterando sua semântica, vigiando o uso social de sua pronúncia, reduzindo o universo vocabular dos fa- 
lantes e, no limite, limitando a capacidade de formular conceitos. Não era outra coisa o que George Steiner queria dizer em seu ensaio sobre a relação entre linguagem e Nazismo (Steiner, 2001) quando ele afirmava que o Nazismo não foi apenas uma questão de política e de repressão. Foi também uma questão de linguagem. Neste sentido, não seria de todo absurdo admitir que, embora vivendo numa ordem formalmente democrática, a deterioração de nossa linguagem - inclusive a educacional-parece indicar que estamos adentrando numa era de vida fascista.

\section{O Clichê na Educação Popular}

Observo que a educação, e especialmente a área da Educação Popular, talvez em função de algumas razões que lhe são bastante específicas (e que tentarei, a seguir, examinar) é um dos campos mais atingidos pela linguagem deteriorada representada pelo clichê, e receio que o problema talvez não seja específico de nenhum campo do saber.

A chamada Educação Popular ficou profundamente marcada, desde os anos 50/60, por uma linguagem de fundo fenomenológico, com suas variantes existencialista e personalista, linguagem que denotava uma profunda crença numa consciência intencional que se debruçava sobre o mundo para lhe oferecer significados e, ao fazê-lo, permitia aos homens a passagem de um estar-no-mundo entre outros para um estar-no-mundo com os outros. Uma atraente concepção de autenticidade da existência humana em contraste com a vida danificada (ou alienada) ganhou especial projeção no vocabulário (ao mesmo tempo simples, de perfil literário, de geometria conceitual variável e adequada a uma época de resistência às formas insidiosas de colonização da consciência) de um autor: o incontornável Paulo Freire!

É, antes de qualquer coisa, evidente que um autor não é inteiramente responsável pela recepção social de sua obra e, sobretudo, pelo uso inadequado dela. Mas, talvez, a melhor indicação para se compreender o fato de uma obra originalmente sofisticada como a de Freire (com suas inspirações hegelianas, personalistas, fanonianas...) ter sido apropriada pelo senso e lugar comum, possa ser dada por ninguém menos do que - lembram-se dele? - ...Gramsci! Gramsci se perguntou, em várias ocasiões (a partir de uma indicação de Marx na Ideologia Alemã), como as ideias podiam se tornar uma força material, e tinha em mente o poder ideológico exercido pela Igreja no Mezzogiorno (sul) italiano. Como é que uma teologia complexa, envolvendo noções de transcendência, ressurreição, onisciência, predestinação, livre arbítrio, graça, onipresença, etc., tinha-se estabelecido no meio das camadas subalternas, desescolarizadas e analfabetas do meio rural sulista italiano? Este foi o seu grande problema político e teórico: transformar filosofia (no caso a da Práxis) em senso comum e bom senso, produzindo uma nova ética política. Este processo se deu, basicamente, através dos chamados intelectuais intermediários, produzindo suas vulgatas, manuais, catecismos, resumos, apostilas...

Educação \& Realidade, Porto Alegre, v. 39, n. 2, p. 557-572, abr./jun. 2014

Disponível em: <http://www.ufrgs.br/edu_realidade> 
O Clichê

Penso que o caso de Freire é semelhante: uma filosofia da educação de pretensões libertadoras, com seu léxico específico e que vinha sendo elaborada desde os anos 50, quer dizer, num momento crucial da discussão sobre a autenticidade nacional, se transformou num lugar comum pedagógico com seu vocabulário deteriorado - o clichê - e o meio operacional que permitiu esta emergência se situa nas inúmeras leituras de Freire, nas adaptações, nas interpretações, nas simplificações, nas transposições... que incontáveis intermediários fizeram de sua obra. O problema, como dizia Mülhmann, a respeito dos messianismos revolucionários do Terceiro Mundo, é que "[...] quando uma ideia se institucionaliza, (num partido, numa igreja, ou mesmo numa Pedagogia) já perdeu a força subversiva original de onde, no entanto, ela retirava toda sua legitimidade" (Mülhmann, 1967, p. 12). Neste sentido, o clichê pedagógico representa a perda do impulso original de onde as palavras, em sua enunciação matinal, retiravam a sua energia semântica. O inesgotável número de leituras e releituras de Freire (uma obra que terminou servindo para dar lastro teórico a toda e qualquer área!), aliado a uma desastrosa simplificação de seu pensamento político e pedagógico terminou facilmente recepcionado por um público que, por motivos que não interessam aqui, identifica-se como oprimido (todos nós!) ou como injustiçado social, econômico, político ou cultural... Estava dado o impulso inicial para a sua banalização, com a inevitável transformação do conceito em slogan e com a garantia de um público certo, de empatia ideológica assegurada, de construção identitária forjada, de autoatribuição de poder simbólico e, last but not least, de benefícios fiduciários oferecidos pela imensa facilidade de captação de recursos públicos para a educação popular!

Vivemos, hoje, o esgotamento prático e teórico do manancial subversivo proporcionado pelas pedagogias da consciência crítica. E isto, na medida em que tais pedagogias não examinaram, a) em que medida a própria criticidade poderia servir aos desideratos do poder, quer dizer, de onde o crítico retirava a força simbólica de sua crítica e a exercia sobre os criticados, lembrando que os criticados não são apenas os dominantes, mas os dominados que não enxergam dentro de si a presença do dominador e, b) a crença iluminista de que haveria uma passagem de uma consciência à outra (o problema estava em se obter a senha que permitiria tal travessia, reservada a alguns). Este esgotamento, aliás, pode ser em parte avaliado pela emergência avassaladora de um novo vocabulário que vem ocupar o lugar antes reservado àquele dicionário crítico que o obra de Paulo Freire tanto inspirava: é uma esquerda recentemente convertida ao gestionarismo (uma das formas que pode assumir a ideologia tecnocrática) que faz de palavras como resultados, avaliação, metas, monitoramento, governança científica, gestão partilhada... o cavalo de batalha linguístico de um (não tão!) novo e insidioso ataque ao que nos resta de vestígio republicano.

Esgotado o manancial, repito, precisamos retomar a matinalidade da consciência ingênua. Proponho, assim, uma inversão da transiti- 
vidade freireana: a passagem da consciência crítica para a consciência ingênua. A proposta pode parecer de uma heterodoxia inaceitável e, no fundo, ...ingênua! Não estou sugerindo aqui uma espécie de revolta rousseauniana contra a linguagem deformada, nem o desarmamento infantil dos espíritos; proponho, numa inspiração que declaro ter sido dada por Pierre Hadot (Hadot, 2001), uma maneira de novamente tornar o mundo estranho, ad-mirável, uma reabilitação da figura nietzscheana da "criança" no Zaratustra. Hadot comenta a habilidade de Marcel Proust em "tornar o mundo estranho", apresentando as coisas de uma forma ainda não contaminada pela explicação causal. Ao nos contentarmos com a abordagem habitual do mundo, linguisticamente expressa pelo clichê, corremos o risco de não notar que este mundo não corresponde mais ao que dele pensamos e dizemos. Para Hadot, a filosofia teria esta função: desfamiliarizar-nos do mundo, tornando-o estranho e devolvendo-lhe um certo potencial de revitalização. Trata-se de algo que Montaigne chamou de naïveté originelle (ingenuidade original): entender menos, assombrar-se mais... são razões que podem levar-nos a ver mais!

Talvez resida aqui, nesta sugestão de ingenuidade, algo relativamente inusitado para nossa concepção de educação popular. E para avançar um pouco mais nesta discussão, teríamos que retomar, exatamente, aquele conceito-chave desta área, o de crítica e seu congênere, o de consciência crítica, conceitos que, no interior de uma determinada tradição pedagógica muito cara à educação popular representam o desejável e decisivo contraponto a uma suposta ingenuidade.

Estou alerta para o fato de que criticar o conceito ou o uso que fazemos da ideia de crítica/consciência crítica é, no fundo, uma operação tautológica em que, para fazê-lo, precisamos nos situar no interior do conceito que pretendemos, no entanto, demolir, o que terminaria por deslegitimar toda pretensão crítica (só o crítico é capaz de desconstruir a crítica)! Não é isto o que pretendo fazer aqui, e sim mostrar como na origem de todo discurso pedagógico - e notadamente naqueles de inspiração libertária ou libertadora - reside algo de irresolvível, um dilema trágico (no sentido agonístico da palavra) original que funda e define o próprio pedagógico, e quero retirar deste exame o seu corolário natural: o exercício da consciência crítica, tal como de ordinário concebemos e praticamos em nossa Educação Popular e, sobretudo, em seu franco contraste com uma consciência dita ingênua (ou, para dizer o mesmo, insatisfatória para municiar os sujeitos em sua relação com a realidade) instala, no coração do pedagógico, uma relação de poder intransparente e difuso da qual não podemos nos libertar sem, ao mesmo tempo, decretar o próprio fim do pedagógico.

O texto fundamental que nos guiará é a clássica Alegoria da caverna (Platão, 1993), texto, a meu ver, fundador da própria filosofia e que nos mostrará como uma simples metáfora da alienação dos homens em sua relação com a realidade obteve um efeito de verdade tão decisivo 
que praticamente definiu a própria pedagogia. Trata-se, assim, de um desses fundamentos discursivos que forneceram à educação uma profunda e duradoura legitimidade secular. Não precisarei, aqui, retomar os detalhes da sobejamente conhecida alegoria platônica e nela sublinharei apenas alguns detalhes que sempre me pareceram curiosamente inexplicáveis. Nesta minha estratégia argumentativa, em que lanço mão daquela passagem platônica, procurarei mostrar - esperando, claro, ser bem sucedido! - que, a) esperar combater o clichê com uma suposta razão crítica contida em pedagogias emancipatórias talvez seja uma tarefa fadada ao fracasso, na medida em que as pedagogias críticas (que a Educação Popular sempre pretendeu encarnar) já foram, elas próprias, contaminadas pelo clichê; b) o recurso à alegoria de Platão nos mostrará que a possibilidade de nos salvarmos pela crítica desveladora do real apresenta um vício de origem: reproduz insidiosamente as injunções hierárquicas de poder e saber que aquela crítica, no entanto, pretende combater e, finalmente, c) o contraponto crítico ao uso e abuso do clichê passa não apenas pela linguagem (sintaxe, semântica, léxico, dicionário conceitual) mas essencialmente, por uma reestruturação do pensar (que a linguagem permite, articula e exprime) que, em meu argumento, chamo de uma renovada consciência ingênua.

Tomemos, então, a célebre Alegoria. Em primeiro lugar, não fica claro no texto de Platão, quem acorrentou os homens daquela forma no interior da caverna; em segundo lugar, não há nada que nos esclareça como foi que um daqueles acorrentados - e por qual razão - resolve se libertar e, ao invés de imediatamente libertar os outros companheiros de, digamos, infortúnio (embora isto também não seja certo!), prefere dar um passeio pelo - sejamos breves -...Céu das Ideias. A questão principal não está na saída do liberto (na verdade, o filósofo) para a luz exterior, mas na sua volta à caverna quando ele tenta convencer seus companheiros a segui-lo em direção à luz e... decepção!, eles preferem a condição em que já se encontravam: estava aqui o mote que iria inspirar Etienne de La Boétie em seu Discurso da Servidão Voluntária, embora neste autor, seja a identificação com o Uno que garante a relação de servidão. Aqui se situa, a meu ver, a metáfora inaugural - para usar um recurso nietzscheano - que, uma vez esquecida e abandonada como metáfora, encerrará a verdade da pedagogia ocidental em cuja origem habita uma dupla fratura: uma na própria realidade e outra entre os próprios homens, sem as quais toda libido educandi se torna rigorosamente impossível.

A primeira fratura diz respeito ao fato de que uma crença se estabelece desde o retorno de nosso liberto à caverna: a crença de que a realidade está dividida em essência (as ideias incontingentes e apenas inteligíveis pela contemplação filosófica) e aparência (reino das sombras, das ilusões e do engano proporcionados pelos sentidos). As consequências disso são profundas e extensas! Sobretudo porque uma dessas instâncias será considerada como primeira e superior à segunda e o acesso a 
ela permitido apenas àqueles que tiveram a coragem de experimentar a dor da passagem da escuridão para a luz e que agora podem retornar ao convívio dos homens na qualidade de condutores qualificados, porque proprietários de um saber (episteme) que os diferenciará dos outros homens. Por que, não custa perguntar, não considerar a sombra ou a aparência como fazendo parte de uma realidade tão essencial quanto àquela representada pelas luzes do Mundo das Ideias? Afinal, caro Platão, não há nada que possamos aprender com a escuridão, com a noite, com a ilusão? Não foi investigando a noite interior dos homens, a caverna subterrânea de seus desejos que Freud chegou a conceber uma teoria e uma terapêutica, tentando salvar os homens das ilusões sobre si mesmos?

A segunda fratura é a consequência da primeira e é ela que introduz o reino da sofocracia, do governo dos que sabem. A origem disto tudo está, como sabemos (mas não custa lembrar) na morte de Sócrates. Diante da Assembleia, o filósofo após demonstrar serenamente a improcedência das acusações (introduzir novos deuses na cidade e corromper a juventude), não consegue convencer seus juízes de seus argumentos, o que terminará na sua condenação (Apologia de Sócrates). Platão nunca aceitou o fato de que o filósofo, homem da Razão e da Palavra, seja vencido pelos representantes da democracia, doravante, mais do que governo do povo, governo da doxa (doxocracia), domínio da simplória e infundada opinião. Eis aqui o significado da segunda fratura: a divisão dos homens entre os que sabem e os ignorantes, a cisão entre doxa e episteme. O homem que se libertou da caverna é o homem da episteme que retorna para salvar seus semelhantes, é incompreendido e retira-se da cidade, acusando a democracia (em larguíssimo sentido muito melhor representada pelos Sofistas, que introduziram no debate público, não o relativismo dissolvente, mas sim, o ponto-de-vista culturalmente situado) de condenar o Logos à morte. Está inaugurada, propriamente falando, a Pedagogia, não como uma teoria que reflete sobre uma prática social - a educação - ou a orienta, mas como um discurso que: a) define a existência de uma realidade essencial que precisa ser alcançada em nome de uma presumível realização da condição humana (e aqui não importa se esta condição se situa no encontro interior com Deus - Santo Agostinho - ou na libertação da opressão - Paulo Freire); b) estabelece que o acesso a esta realidade (do saber, da libertação, do aperfeiçoamento), opondo certas e compreensíveis dificuldades, não pode ser realizado sem o auxílio de alguém que, através de um gesto sobre si mesmo (dedicação aos estudos, reflexão, sacrifício da libertação) já teve acesso a ela e pode, agora, se apresentar como detentor de uma qualidade ausente nos outros; c) define e qualifica a carência do Outro; d) transforma o Outro em objeto pedagogizável; e) promete realizar a travessia, a condução (gogein) que levará da sombra à luz.

Se levarmos a sério a boutade de Whitehead - "Toda a filosofia ocidental não passa de anotações à margem do texto de Platão!” (Russ,

Educação \& Realidade, Porto Alegre, v. 39, n. 2, p. 557-572, abr./jun. 2014. 
2001, p. 201), observaremos que o horizonte dualista inaugurado pelo autor da República (sobretudo a fratura relativa à divisão entre os homens de que falei acima) se reproduziu no tempo sob linguagem vária, mas semanticamente semelhante: consciência de classe X alienação (Marx); classe em si X classe para si (Lukàcs); ser em si X ser para si (Sartre); senso comum X consciência filosófica (Gramsci); cultura primeira X cultura elaborada (Georges Snyders); código restrito X código elaborado (Bernstein); consciência ingênua X consciência crítica (Paulo Freire)..., sem o que, volto a insistir, todo enunciado pedagógico perde boa parte de sua legitimidade, entendido que o pedagógico é exatamente aquilo que vai se situar entre um e outro termo de cada um dos dualismos assinalados.

Quem é este Outro que toda educação precisa instituir como objeto pedagogizável, sem o qual ela se vê carente de todo fundamento discursivo? A questão central desta instituição do Outro pelo pedagógico está em definir e qualificar a sua carência, cotejando-a com um certo ideal (humano, social, espiritual, intelectual, moral, civilizacional) a ser alcançado, sem o que nossa condição humana restará insuficiente e precária. O povo, a criança, a mulher, o colonizado, o infiel, o bárbaro, o índio e, finalmente, todos os homens. Aqui estamos praticamente nos remetendo ao entendimento de que o discurso pedagógico é aquele que, ao configurar um ideal humano a ser alcançado (mesmo que como ideia reguladora), define, no mesmo movimento, a carência do Outro, entroniza de forma institucional aqueles que dispõem da competência para conduzir a transição de um ponto ao outro, em torno do que se constrói um complexo sistema educacional de atribuição de qualificação e de certificação social. Entendo a educação como as práticas sociais, institucionalizadas ou não, envolvendo agentes com papéis relativamente bem definidos que permitirão, bem ou mal, a realização do discurso pedagógico: a transitividade da carência para o ideal, com a utilização de recursos didáticos, arquitetônicos, bibliográficos, materiais e humanos para sua consecução. O pedagógico funda e legitima aquilo que o educativo faz no interior de uma relação intersubjetiva específica: a relação entre educador e educando.

Se tomarmos a metáfora da caverna (na verdade, da vida não refletida ou alienada) como o momento original de uma pedagogia, de uma condução dos homens para a luz, entenderemos que a posição do Crítico (figura situada entre a melancolia - por sua insatisfação com o mundo - e a utopia, por sua vontade de criar um novo mundo) não pode jamais se separar de injunções hierárquicas, o que faz com que no subterrâneo inconfesso de toda crítica encontremos uma múltipla face: aquela voltada para a análise de toda realidade e de sua condenação pela Razão reordenadora; a condenação dos homens incapazes de enxergá-la; uma libido dominandi: impor à realidade e aos homens comuns sua melancolia e sua utopia. 
Quando é a própria realidade que não responde mais ao seu enquadramento conceitual - proposto pelos intelectuais - e precisamos de amparo linguístico para nomear experiências e se refamiliarizar com um mundo tornado estranho, entra em cena o clichê, que entre outras coisas, termina por garantir que a velha ordem não mudou, que o mundo ainda é perfeitamente compreensível e visível pelas antigas lentes e que, finalmente, ainda temos legitimidade para propor mundos novos...

\section{Algumas Palavras Finais...}

Aquela condição inaugural do pedagógico, acima esboçada, marca decisivamente nossa Educação Popular e, com ela, uma forma de relação que esconde a natureza hierárquica da crítica/consciência crítica. E o léxico que usamos para designar estas experiências está definitivamente marcado por esta relação. Talvez resida aqui a imensa tarefa que nos espera enquanto educadores: a construção de um novo vocabulário, um novo dicionário capaz de nos colocar novamente diante do absurdo sisífico que toda realidade alberga. A derrocada do pensar que representa o uso do clichê em assuntos educativos, instala-nos diante da real possibilidade de nos afastarmos do mundo, de nos impedirmos a experiência e sua eventual (re)conceitualização, de nos fecharmos num universo vocabular tranquilizante e acolhedor e, assim, pararmos de ver o mundo com olhos de estranhamento, com óculos ingênuos. Mas é exatamente isto que todos os tiranos sempre desejaram!

Recebido em 08 de outubro de 2012 Aprovado em 15 de janeiro de 2013

\section{Notas}

1 Devo a Alain Finkielkrault a ideia de derrota do pensamento extraída de um de seus livros (Finkielkrault, 1987). No entanto, naquele livro, o filósofo francês analisa, a partir de uma ideia de Julien Benda, uma espécie de nova traição dos intelectuais que aderiram, impensadamente, às modas multiculturais, ao relativismo cultural dissolvente e abandonaram as perspectivas universalistas que nos permitiam ir além do paroquialismo da minha cultura.

2 Baseio-me, aqui, na edição francesa de 1994.

3 Uso, aqui, o conceito de ideologia num sentido distinto daquele que nos foi fornecido pelo marxismo (quer dizer, como falsa consciência, como inversão da realidade, como interpelação dos indivíduos em sujeitos ou como ideias e valores impostos pela classe dominante numa determinada situação histórica e social). Faço uso da ideia num sentido próximo ao de Arendt, em que ideologia remete aos automatismos do pensar, expresso sob a forma de clichês, impedindo o pensamento de a) se voltar sobre si mesmo (re-flexão) e b) cotejá-lo com a ação e fazer da vida vivida (vivência), vida refletida (experiência) (Arendt, 1996).

Educação \& Realidade, Porto Alegre, v. 39, n. 2, p. 557-572, abr./jun. 2014.

Disponível em: <http://www.ufrgs.br/edu_realidade> 


\section{Referências}

ADORNO, Theodor; HORKHEIMER, Max. Dialética do Esclarecimento. Rio de Janeiro: Zahar, 1987.

AQUINO, Júlio Groppa; CORAZZA, Sandra. Dicionário de Ideias Feitas em Educação. Belo Horizonte: Autêntica, 2011.

ARENDT, Hannah. A Condição Humana. Rio de Janeiro: Forense, 1997.

ARENDT, Hannah. Eichmann à Jerusalem. Rapport sur la banalité du mal. Paris: Gallimard-Folio, 1994.

ARENDT, Hannah. La Vie de l'Esprit. La pensée. Paris: PUF, 1996

CAMUS, Albert. Le Mythe de Sysiphe. Paris: Gallimard-Folio, 2001.

COLLIN, Françoise. L’Homme est-il devenu Superflu? Paris: Odile Jacob, 1999.

ECO, Umberto. Os Limites da Interpretação. São Paulo: Difel, 2004.

FINKIELKRAULT, Alain. La Défaite de la Pensée. Paris: Gallimard-Folio, 1987.

HADOT, Pierre. La Philosophie comme Manière de Vivre. Paris: Albin Michel, 2001.

MÜLHMANN, Alfred. Messianismes Révolutionaries du Troisième Monde. Paris: Editions de Minuit, 1967.

PLATÃO. La République. Paris: Folio-Essais, 1993.

ROVIELLO, Anne-Marie. Sens Commun et Modernité chez Hannah Arendt. Paris: PUF, 1991.

RUSS, Jacqueline. La Marche des Idées Contemporaines. Paris: Armand Colin, 2001.

STEINER, George. Langage et Silence. Paris: Gallimard-Folio, 2001.

YOUNG-BRÜHEL, Elizabeth. Hannah Arendt: por amor ao mundo. Rio de Janeiro: Relume Dumará, 1997.

Flávio Henrique Albert Brayner é professor titular da Universidade Federal de Pernambuco, tem doutorado e pós-doutorado pela Université René Descartes-Paris V (Sorbonne), foi Maître de Conférence da Université de Montpellier III e é Coordenador do GT 06 (Educação Popular da ANPEd)

E-mail: flaviobrayner@hotmail.com 